\begin{tabular}{ccc}
\hline & International Journal of Engineering \& Technology, 7 (2.29) (2018) $469-475$ \\
SPC & International Journal of Engineering \& Technology \\
\hline
\end{tabular}

\title{
Economic Evaluation of Landscape Integrated Pest Management Programs in Banyumas Regency, Central Java, Indonesia
}

\author{
Hani Perwitasari *, Irham, Slamet Hartono, Suhatmini Hardyastuti \\ Department Of Agricultural Socio-Economics, Universitas Gadjah Mada, Yogyakarta, Indonesia \\ *Corresponding Author E-Mail: Hani.Perwita@Ugm.Ac.Id
}

\begin{abstract}
The massive use of chemicals in food production process has adversely affected the aspect of cost, ecology and health in particular. Landscape Integrated Pest Management (LIPM) Program is one of the technology applications targeted to minimize the chemicals. In Indonesia, there were only 6 regencies which applied LIPM, which included Banyumas regency. This study primarily aims at comparing production costs, productivity, revenue, profit and financial feasibility between LIPM and non-LIPM rice farms. The researchers collected primary and secondary data during the investigation. They purposively chose Pliken Village as the research object as it is the only village implementing LIPM. Meanwhile, sample was selected by random sampling methods involving LIPM and non- LIPM farmers with 30 respondents for each. Independent-samples $\mathrm{T}$ test was exerted to compare productivity, revenue, cost, profit and financial feasibility. The results indicate that productivity, revenue, profit and financial feasibility farming with LIPM were higher than the non-LIPM farming. Moreover, the production cost in the LIPM farming was lower than the production cost of the non-LIPM farming. The independent T-test pinpoints that the total revenue indicator and profit were significant. In other words, it may become reference to encourage farmers to apply Landscape Integrated Pest Management Program for sustainable agriculture
\end{abstract}

Keywords: Economic evaluation, LIPM, banyumas

\section{Introduction}

In agriculture, one of the most common problems is pests which may disrupt the plants' growth and lead to a dwindling down plantation's productivity. To overcome that pestering pest problem, farmers have attempted several strategies to eradicate the plant ravaging pests. The most widely used measurement to control the pests is using chemicals. However, massive use of chemicals in the production process is proven to trigger adverse impacts in some aspects. In addition, in terms of cost, pesticide usage raises the farmers' outlay which means a decreasing profit of their sold agricultural products. In the matter of ecology, using pesticide might cause land degradation which eventually will affect the agricultural crops. In the matter of health, the remnant of chemical substances being left in the products passed down from the farmers and consumers might be poisoning human's health. The negative effects brought by the massive usage of pesticide pinpoints a disconcerting fact that healthy foods production system has not been established yet. (1) did some researches on "Pengelolaan Hama Terpadu Skala Luas (PHTSL) / Landscape Integrated Pest Management" in several regions of Java Island. The implemented PHTSL made a good use of refugee flowers as an alternative in agricultural pest control. Bougainvillea, Four O'Clock Flower (Mirabilis Jalapa), sunflower (Helianthus Annuus L.), and Yellow Alder (Turnera Ulmifolia) are kinds of flowers attracting their natural enemy insects. On the basis of the research, it is well proven that planting refugee flowers has been significantly effective on cutting down the use of pesticide and boosting the agricultural productivity.
Pliken Village is one of PHTSL's study objects that use refugee flowers as studied by FAO. Pliken Village is one of the villages situated in Kembaran, Banyumas. The area is a potentially promising for agricultural field with farming as their dominating bread and butter. It is noteworthy that rice production in Pliken Village's in one time of harvest amounted to 6.5 up to 7 tons per hectare. Farmers have applied cropping pattern for paddy-paddy-palawija. The most commonly planted rice varieties in Pliken Village is mekongga, situ bagendit, and IR-64. While for palawija (non-rice low water consuming crops), corn and soybeans are the most popularly cultivated. To water the plantations in Pliken Village most of farmers apply technical, semi technical, and non-technical irrigations. For now, there are three farming groups out of five involved as the research object in Pliken Village. Although the remaining two groups were not involved as research objects, the knowledge collected from the three farming guided groups is disseminated to the other two farming groups. The knowledge-dissemination activity as conducted by fellow farmers in one village enhances the possibility to develop Pliken Village as a tourist village or transplant nursery center. For that, eco-friendly pest eradication using refugee flowers could be applied and developed in Pliken Village in order to expand the area's farming sector. However, there are still quite some numbers of farmers of Pliken Village that count on chemical substancesbased pest control weapons such as pesticide to eradicate the pests, especially rice. Besides relying on chemicals for pest control, there are also countless farmers of the village using chemicals as the fertilizers. So, in order to reduce the use of chemicals for rice farming in Pliken Village, a study of economical evaluation of Integrated Pest Management Landscape application in the village is necessary to inspire other chemical user farmers. 


\section{Literature Review}

\subsection{Landscape Integrated Pest Management Concept}

Some definitions of Integrated Pest Management (IPM) are brought by (2) propounded that IPM is choosing, mingling and applying pest management that is based on the calculation and assessment of economical, ecological, and sociological consequences. On the other hand, according to (3), IPM's concepts and approaches deal with an agro-ecosystem managing concept to maintain the pests' population and the plants' damages which affect the cedars that put no harm on anything, by combining and utilizing all pest management methods, including the utilization of the predators and parasitoid, long-lasting varieties, farming techniques and others. It may also use selective pesticide when needed.

In accordance to the Indonesian law and regulations, IPM is regulated in the law number (4) pertaining to plant cultivation, article 1 section 7 on plants' conservation as every endeavor to prevent detrimental effects of planting's cultivation affected by organisms that harm the plants. While article 1 section 2 propounded that harmful plantsare organism which might ruin the lives or take life of the plants.

In addition, the (5) on Plant Protections regulates that integrated pest management is needed to keep the plants safe through various management techniques in one planning. It may be done in the area that comprises physical ways, mechanics, cultivation, biology, genetics, chemicals, and any other ways that are relevant to the growth of technology.

In the vein of the previous IPM definition, (6) also defines IPM as a system that supports the decision for choosing and using pest management strategies, whether done singly or en masse, it has to be coordinated with the management strategies based on the cost/advantage analysis that deals with the interests and effects of the producers, society, and environment.

There are some fundamental elements to apply, which are: natural control, economic levels, and deeper understanding in biology and ecology from every kind of insects that matters in that system. Every element is vital and gives off bigger support to all of the components which may be applied and adjusted in every pest management operation. Natural control is a control that utilizes predators and parasites or biological controls that happens out in the open. In this case, if the pests' population is lower, it is possible that they may belong to non-threatening pests. Economic levels or economic threshold is up until the pests' population level, so that management needs to be started to prevent any further economic damages from the cultivated plants. Therefore, biological and ecological understandings about pests and useful insects is crucial in building a management strategy especially in pests and diseases control (7).

According to (8), IPM as an approach and OPT (Plant Disturbing Organisms) management technology which roots in economy and ecology has been addressed by national plantation security's fundamental policy. It plays a huge role in solving the problems in plants' security in this globalization era and regional autonomy. There are four fundamental principles that stimulate IPM application nationally, mostly in terms of sustainable construction that is based on environment (9)

\subsection{Healthy plants cultivation}

Cultivating healthy plants has become crucial in pest and disease management program. Healthy plants will withstand against pests' and diseases attacks and take less time to get over the damages caused by the attacks. Given such condition, every cultivation process such as varieties selecting, seeding, plants' maintenance and harvesting greatly require attention to yield in healthy, vigorous, and productive plants.

\subsection{Utilizing natural enemy}

Biological control by making use of potential natural enemy is the main goal of IPM. The existence of natural enemy able to curb pests' population may help balancing both sides - the pests population and the natural enemy's - to avoid excessive pests population against the tolerance threshold.

\subsection{Routine observation and monitoring}

Agro ecosystem is dynamic because it involves many influential things one another. Regular observation is required to keep up with the growth of pests' population, their natural enemies', and also the plants' conditions. Meanwhile the information gained will be used as the foundation for the next step.

\subsection{Farmers as IPM specialists}

It is advisable to adapt IPM application to the current ecosystem conditions of the village. It is also highly suggested that IPM recommendation be developed by the farmers themselves. Correctional IPM cultivation is needed in order that they apply IPM through both formal and informal proper training.

One of the mechanisms in Integrated Pest Management is Landscape Integrated Pest Management. Pengendalian Hama Terpadu (PHT) Lanskap/Landscape Integrated Pest Management (LIPM) encourages sustainable "healthy" rice production and ensures more effective pest management through development towards the pests' communal handling in an area (landscape) (1). Essentially, LIPM's principle is the same as IPM. To implement this program, FAO teams up with the Indonesian Agricultural Office through Sekolah Lapangan Hama Terpadu (SLPHT/Field School of Integrated Pest Management)

\subsection{Sekolah Lapangan Pengendalian Hama Terpadu (SLPHT/Field School of Integrated Pest Management)}

SPLPHT is a school in the open without any barriers or walls. Classes are held out in a field and guided by a field guide who teaches IPM materials. This method requires a school, curriculum, decent laboratory (10) complemented by a graduation token (11). Approaches and training patterns are the primary considerations during the process of simple study. The method aims to change the farmers' behaviors from their old habits of using pesticide intensively into environmental-friendly pest management that focuses on natural eradication (12).

SLPHT's activities go on all along one full season, in which "inclass" meeting is held once a week in the morning with at least 6 effective hours. The activities comprises of field work, agro-ecosystem observation, drawing agro-ecosystem, sub-group discussion, plenary discussion (presentation), specific topic, group dynamics, executing special studies, and IPM application practice in farming (11).

In SLPHT, the farmers learn to find the answer of actual problems they encounter through the SLPHT learning process which covers some steps namely undertaking, experiencing, expressing, analyzing, concluding, and applying. SLPHT is characterized by the existence of agreement/study contract, decisions taken together, integrated exercise and practice materials in a farm by learning through adult's education experience. The main goals of SLPHT are to change the farmer's demeanor so that they understand, have a will, and are capable to apply the 4 principles of IPM, and to socialize IPM itself. In addition, SLPHT' holds a principle of considering: the farm as the main studying medium, learning from experience, agro-ecosystem assessment, practical but useful methods, and curriculum based on the farmer's needs (13)

\subsection{The Economic Impact of IPM}

Based on (14) who examined the performance of rice pest control after the introduction of integrated pest control technology, it can be concluded that in a single process of production, it takes a pest control cost of Rp.94,260, - (9\% of total cost) which consists of cost pprocurements of pesticides (64\%) and wage application (36\%). 
The old method (the majority applied Non-SLPHT) requires a greater cost of control than the IPM method (applied to SLPHT farmers). The study by (15) also shows that there was a significant difference between the usage level of pesticides on SLPHT participating farmers and non-participants of SLPHT where in the latter the use of pesticide is higher than in the participating farmers. This shows that non-participant farmers still use pesticides in controlling existing pest attacks.

Furthermore, earned economic profit increased from 455 USD / ha to 1,287 USD / ha (16). According to (17) the production of cabbage farmers of IPM participants is higher than that of the Non-IPM farmers. In addition, income and profits from cabbage farming of farmers participating IPM programs are higher than that of the non IPM farmers, as IPM farmers can reduce the cost of pesticides which significantly affects the income and profit received. A research by (18), showed that SLPHT can improve knowledge and skills of farmers in implementing IPM. Further, the results show that the application of IPM planted cotton can improve yield and profit of cotton farming, and improve condition of cotton agro-ecosystem in farmer cultivation area. This is supported by (19) pinpointing that economic factors significantly affect the application of IPM to farmers who join SLPHT and for farmers who do not join the SLPHT. In 2008, (20) conducted a research on IPM technology for more than 20 years. Based on the economic evaluation, the use of IPM in managing pests of rice invertebrates in NSW as it is known that the adoption of IPM among NSW rice farmers shows the flow of economic benefits for the rice and community industries and that important environmental and human health benefits are also identified. The 9.05 cost-benefit ratio is known to be related to the investment of NSW DPI invertebrate rice pests using IPM. The net present value of the benefits of this research for 2020 is $\$ 67.9$ million. In addition, (21) also shows that IPM programs will generate economic benefits which includes water quality improvements, food security, pesticide application security, and long-term sustainability length of pest management system. In terms of environmental and cost savings, the reduction of pesticide use also reduced business expenses.

\section{Methodology/Materials}

\subsection{Basic Methods}

This research applies the analytic descriptive method. Descriptive research gives a brief picture of certain social economic phenomenon and circumstances, which in this case are the economic evaluation of rice agriculture in Banyumas regency. In addition, the purpose of this descriptive research is to describe systematic picture, actual fact, character, and corelation between the investigated phenomena. The analytic research is used for the statistical hypothesis test.

\subsection{Sample Collection Methods}

Rice farmers in Banyumas Regency are set as the research population. Sample collection on sub-regency, village, and group of farmers are done purposively by considering the use of Landscape Integrated Pest Management (LIMP) as a central issue in rice production. Sample collection is carried out with simple random methods with 30 farmers that apply LIMP and 30 farmers that do not. The primary data are gathered from primary sources through observation and interview. The secondary data are gathered through studies on the related research.

\section{Analytical Methods}

\subsection{Productivity Comparison and Rice Farming Reve- nue}

Productivity is the yield crops of rice commodity from farmers with or without LIMP usage per acres of land. Revenue is acquired from the formula TR=P.Q ( $\mathrm{P}$ is the price of rice commodity and $\mathrm{Q}$ are rice farming efforts). The hypothesis for the comparison of production and rice farming revenue between farmers with and without LIMP are as follows:

Ho : $\mu_{1}=\mu_{2}$, which means the production and rice farming revenue of farmers utilizing LIMP are the same with the that of farmers without LIMP.

Ha : $\mu_{1} \neq \mu_{2}$, which means the production and rice farming revenue of farmers utilizing LIMP are not the same with that of the farmers without LIMP.

On two independent-samples $\mathrm{t}$ test, $\mathrm{t}$-test are used to test the similarity of 2 independent population. T-test is the perfect test to reject Ho (22).

The formula for the t-test is:

$$
t=\frac{\left\lfloor\overline{X_{1}}-\overline{X_{2}}\right\rfloor}{\sqrt{\frac{S_{1}^{2}}{n_{1}}+\frac{S_{2}^{2}}{n_{2}}}}
$$

With the variety of each:

$$
S^{2}=\frac{\sum\left(X_{i}-\bar{X}_{1}\right)^{2}}{n-1}
$$

Where:

$\mathrm{X}_{1}=$ Production and rice farming revenue of farmers with LIMP

$\mathrm{X}_{2}=$ Production and rice farming revenue of farmers without LIMP

$\mathrm{S} 2 \mathrm{x} 1=$ standard deviation of rice farming sample of farmers with LIMP

$\mathrm{S} 2 \times 2=$ standard deviation of rice farming sample of farmers without LIMP

$\mathrm{n} 1=$ amount of rice farming sample of farmers with LIMP

$\mathrm{n} 2$ = amount of rice farming sample of farmers without LIMP

\subsection{Cost Structure Comparison of rice farming}

Production cost count are collected by adding permanent fees with variable fees which is mathematically described as follows:

$$
T C=F C+V C
$$

Cost structure is also examined by average difference test of two samples. T-test is used to examine the average similarity from two dependent populations. T-test is the most suitable test for denying null hypothesis. The comparison of cost structure of rice farming applying LIPM and the farmer who do not apply LIPM may be described through the following hypothesis:

Ho : $\mu_{1}=\mu_{2}$, is cost structure of rice farming which applies LIPM that is similar with that of farmers who do not apply LIPM.

Ha : $\mu_{1} \neq \mu_{2}$, is cost structure of rice farming which applies LIPM that is not similar with that of farmers who do not apply LIPM.

$T$ statistic which is used means:

$$
t=\frac{\left\lfloor\overline{X_{1}}-\overline{X_{2}}\right\rfloor}{\sqrt{\frac{S_{1}^{2}}{n_{1}}+\frac{S_{2}^{2}}{n_{2}}}}
$$

By using variant for each item:

$$
S^{2}=\frac{\sum\left(X_{i}-\bar{X}_{1}\right)^{2}}{n-1}
$$

Where:

$\mathrm{X}_{1}=$ cost structure of rice farming sample applying LIPM

$\mathrm{X}_{2}=$ cost structure of rice farming sample not applying LIPM

S2x1 = deviation standard of rice farming sample applying LIPM

$\mathrm{S} 2 \times 2=$ deviation standard of rice farming sample not applying LIPM

$\mathrm{n} 1=$ number of rice farming sample applying LIPM

$\mathrm{n} 2=$ number of rice farming sample not applying LIPM 
3.3.1.3 The comparison of Profitability and feasibility of farming business

Profit is the difference between cash income and the total cash, also with total cost. Mathematically, it can be written as follows: $\Pi=$ TR - TC

The feasibility of farming business with and without LIPM may be revealed through $\mathrm{R} / \mathrm{C}$ ratio with the formula $\mathrm{R} / \mathrm{C}=$ Total income/Total cost, if value of $\mathrm{R} / \mathrm{C}$ ratio is more that $1(\mathrm{R} / \mathrm{C}>1)$, which means that the business is feasible.

If $\mathrm{R} / \mathrm{C}$ ratio is less than $1(\mathrm{R} / \mathrm{C}<1)$, this means that the business is not feasible.

If $\mathrm{R} / \mathrm{C}=1$, this means that the business reach the break-even point. The comparison of profitability and feasibility of rice farming for farmers with LIPM and those without LIPM may be drawn out through the following hypothesis:

Ho $: \mu_{1}=\mu_{2}$, is the profitability and feasibility of rice farming of farmers with LIPM which is similar to the profit and feasibility of rice farming of farmers without LIPM.

Ha : $\mu_{1} \neq \mu_{2}$, is the profit and feasibility of rice farming of farmers with LIPM which is not similar to the profit and feasibility of rice farming of farmers without LIPM.

It may be calculated through the following $\mathrm{T}$ statistics:

$$
t=\frac{\left\lfloor\overline{X_{1}}-\overline{X_{2}}\right\rfloor}{\sqrt{\frac{S_{1}^{2}}{n_{1}}+\frac{S_{2}^{2}}{n_{2}}}}
$$

The variant for each item is formulated as follows:

$$
S^{2}=\frac{\sum\left(X_{i}-\bar{X}_{1}\right)^{2}}{n-1}
$$

Where:

$\mathrm{X}_{1}=$ Profit and feasibility of farming business sample with LIPM. $\mathrm{X}_{2}=$ Profit and feasibility of farming business sample without LIPM

S2x1 = deviation standard of farming business sample with LIPM. S2 $22=$ deviation standard of farming business sample without LIPM.

$\mathrm{n} 1=$ number of farming business with LIPM.

$\mathrm{n} 2=$ number of farming business without LIPM.

Afterwards, the t value was compared and that each estimator was calculated with critical $t$ from the table using the following criteria: If calculation of $t$ value is $>t$ table, Ho is denied and $\mathrm{Ha}$ is accepted, which means that there is $\mathrm{RC}$ ratio difference from farming business with and without LIPM

If calculation of $t$ value is $<\mathrm{t}$ table, Ho is accepted and $\mathrm{Ha}$ is denied, which means that there is no $\mathrm{RC}$ ratio difference from farming business with and without LIPM

\section{Results and Findings}

\subsection{The characteristics of Rice Farming in Banyumas Regency}

'The characteristics of rice farmers in Banyumas Regency refer to the farmers' social and economic conditions in the research location. These characteristics include the age of the farmer, the level of education, the area of arable land, and the number of members of the family. An analysis to know the effect on the management of farms by the farmers may be based on the following characteristics.

\subsection{Land Area}

Land area is one of the important factors in the production process or farming. In farming activities, the land used on the basis of its tenure can be divided into one's own land, rented/leased land and sharecropping. The average land area used in rice farming in Banyumas Regency is as illustrated in table 1 .
Table 1: The Average Land Area used in Rice Farming in Banyumas Re-

\begin{tabular}{|c|c|c|}
\hline \multirow{2}{*}{ Status of Land Tenure } & \multicolumn{2}{|c|}{ Land Area $\left(\mathrm{m}^{2}\right)$} \\
\hline & LIPM & Non-LIPM \\
\hline Own Land & $5,045.72$ & $4,994.33$ \\
\hline Rented / Leased & $4,333.33$ & $6,166.67$ \\
\hline Sharecropping & $4,962.50$ & $4,489.82$ \\
\hline Total & $14,341.55$ & $15,650.82$ \\
\hline
\end{tabular}
gency in 2016

Based on Table 1, it is obvious that the majority of Integrated Pest Management (IPM) farmers tilled their own land, followed by those doing the shared crops and renting/leasing the land as the least proportion. Such occurrence is due to the fact that rice cultivation through IPM is more risky. On closer look, most non-IPM rice farmers use leased lands in farming rice. The significant amount of leased land use in rice farming means that farmers want to obtain a larger production even though they do not own land. The bigger the land area used in farming, the more production they will yield. The area used by non-IPM rice farmers is higher than that by the IPM farmers because farmers prefer a practical way, especially in tackling pests and in understanding the importance of environmentally friendly farming.

\section{Identity of rice farmers}

\subsection{The Identity of Rice Farmers based on Age}

Age is one factor that affects farming. The older one gets, the more farming experiences one has. At the same time, one may suffer from decreasing physical strength. The age factor will greatly affect the work that relies heavily on physical strength and abilities of the workforce. As in the case of farm laborers in sugar cane farming, age will greatly affect the productivity of its work because it relies heavily on physical strength. On the other hand, the older one gets, the higher the work experience one learns to avoid the occurrence of crop failure. The age of the population can be grouped into three groups; young or unproductive age group ranging from 0-14 years, adult or productive age group ranging from 15-64 years, and the last is old age or unproductive age, ranging from 65 years and above. The identity of the heads of the rice farming family in Banyumas Regency is illustrated in table 2 .

Table2 Identity of the Heads of the Rice Farming Families in Banyumas Regency in 2016

\begin{tabular}{|c|c|c|}
\hline \multirow{2}{*}{ Age (Years) } & \multicolumn{2}{|c|}{ Percentage (\%) } \\
\cline { 2 - 3 } & LIPM & Non-LIPM \\
\hline $\mathbf{1 5}-\mathbf{6 4}$ & 70.00 & 60.00 \\
\hline $\mathbf{6 4}$ & 30.00 & 40.00 \\
\hline Total & 100.00 & 100.00 \\
\hline
\end{tabular}

The majority of the heads of both IPM and non-IPM rice farming families in Banyumas Regency may be included in the age group of 15 - 64 years i.e. adult age or productive age. This pinpoints that most of the heads of rice farmers in Banyumas Regency are physically strong and productive so that they can still adopt technology and innovation, and support the increasing productivity of rice farming.

\subsection{The Identity of Rice Farming based on Education Level}

Farmer's level of education is closely related to farmers' ability to adopt new technology to support the optimization of input use in their rice farming. The higher the farmer's level of education, the easier they will adopt technology they gain knowledge from the agricultural counselors which is expected to increase the production of rice farming. 
Table 3: The Identity of Heads of Rice Farming Families Based on their Education Level in Banyumas Regency in 2016

\begin{tabular}{|c|c|c|}
\hline \multirow{2}{*}{ Educational Level (Years) } & \multicolumn{2}{|c|}{ Percentage (\%) } \\
\cline { 2 - 3 } & LIPM & Non-LIPM \\
\hline $0-6$ & 63.33 & 86.67 \\
\hline $7-9$ & 6.67 & 10.00 \\
\hline $10-12$ & 23.33 & 3.33 \\
\hline$>12$ & 6.67 & 0.00 \\
\hline Total & 100.00 & 100.00 \\
\hline
\end{tabular}

Table 3 shows the distribution of education level of the heads of rice farming families in Banyumas Regency. It can be seen that the education level of the heads of the rice farming families in Banyumas Regency is fairly low with the highest percentage of 0-6 years. This can hamper the level of aspiration and knowledge to apply new innovations and technologies. This is supported by the fact that more IPM farmers have higher education than the non-IPM farmers.

\subsection{The Use of Production Factor (Input)}

In the aspect of rice farming production, the level of land use for rice farming in Banyumas Regency is known. The use of input or input factors, either variable or fixed inputs, can be distinguished into two, i.e. the use of IPM and non-IPM rice inputs. In the production of rice, the difference in the average amount of production factors used by IPM and IPM farmers in Banyumas regency can be clearly seen.

The production factors used in these two types of rice fields include: number of rice seeds; amount of Urea fertilizer; amount of Phonska, ZA and manure / organic fertilizer; amount of pesticides; the number of labors used for this purpose, both labor from the family members and labor from outside the family. Table 4 describes the average use of production factors per planting season between IPM and Non-IPM farms in Banyumas Regency.

Based on Table 4.4, it is obvious that the input components for IPM and Non-IPM farming are relatively similar. It differs significantly in the use of fertilizer, especially manure or organic fertilizer. In addition, the use of organic fertilizer is only found among the IPM farmers while non-IPM farmers do not use organic fertilizers. Types of organic pesticides used by the IPM farmers are STMJ and Chorine Bacterium. The IPM farmers also use refugee plants as biological agents planted in the area of $13.59 \mathrm{~m}$. This difference in use can be attributed to the participation of IPM farmers in SLPHT (Field School of Integrated Pest Control). In these activities, farmers are given counseling to become managers who can solve problems on their farms independently, especially in the improvement, skills and attitude of farmers in the management of OPT (Plant Disturbing Organisms).

Table 4: The Average Use of Production Factors per Planting Season in Rice farming in Banyumas Regency in 2016

\begin{tabular}{|c|c|c|c|}
\hline Production Factor (Input) & Unit & LIPM & Non-LIPM \\
\hline Seeds & $\mathrm{Kg}$ & 33.31 & 33.50 \\
\hline Urea Fertilizer & $\mathrm{Kg}$ & 260.94 & 200.17 \\
\hline Phonska Fertilizer & $\mathrm{Kg}$ & 97.34 & 82.00 \\
\hline ZA Fertilizer & $\mathrm{Kg}$ & 0.31 & 1.33 \\
\hline Manure/Organic & $\mathrm{Kg}$ & 345.78 & 140.67 \\
\hline NPK Fertilizer & $\mathrm{Kg}$ & 1.50 & 0.00 \\
\hline Chemical Pesticides & $\mathrm{L}$ & 0.01 & 0.30 \\
\hline Organic Pesticides & $\mathrm{L}$ & 1.20 & 0.00 \\
\hline Labors & $\mathrm{HOK}$ & 47.47 & 34.07 \\
\hline In family & $\mathrm{HOK}$ & 11.78 & 10.60 \\
\hline Outside family & $\mathrm{HOK}$ & 35.69 & 24.47 \\
\hline
\end{tabular}

\subsection{Productivity and Total Revenue of Rice Farming in Banyumas Regency}

Productivity is the result of the cultivation of rice commodities by farmers per acre of land area and the revenue of farming is derived from the total rice production produced during one planting season and multiplied by the market price at that time. Farmers who apply LIPM yield products with little residue of pesticide chemicals.

Table 5: Productivity and Total Revenue of Rice Farm in Banyumas Regency (per Ha)

\begin{tabular}{|c|c|c|}
\hline Description & LIPM Farm & Non-LIPM Farm \\
\hline Productivity (quintal) & $7,0202.17$ & $6,668.77$ \\
\hline Total Revenue (Rp) & $58,162,910.12$ & $37,066,224.34$ \\
\hline
\end{tabular}

Based on Table 5, it is noticeable that the productivity and the total revenue that the LIPM farmers receive is higher than that of farmers without LIPM. This is due to the fact that the farmers who apply LIPM were previously trained by SLPHT so that they can manage their farming efficiently. In addition, the price of the products produced by the farmers applying LIPM is higher than that produced by the Non-LIPM farmers, especially for farmers whose products have received Prima III certification. The certificate indicates that the product does not use pesticides. The price of the certified product is about Rp15,000/ kg while the price of the uncertified product is around $\mathrm{Rp} 12,000 / \mathrm{kg}$.

Provided the analysis of the difference test of the average farming productivity between LIPM farming and non-LIPM farming, it is understandable that the significant value in F test column is 0.84 ; it is not assumed to be the same variance so that from the T-test column the value shown is 0.74 for the 2 -tailed test where this value is greater than the degree of error of $10 \%$ which means that $\mathrm{HO}$ is accepted. In other words, the productivity of the LIPM and Non-LIPM farms is not significantly different.

Table 7 shows the analysis results of the difference test on the average revenue between LIPM and Non-LIPM farmers, in which a significance value of 3.41 in the F-test column is obtained. Then, it is not assumed as the same variant. Therefore, from the T test column the value indicated is 0.04 for the 2 -tailed test where this value is less than the $5 \%$ margin of error which means $\mathrm{H} 0$ is rejected. In other words, the revenue received by LIPM farmers and Non-LIPM farmers is significantly different at the $95 \%$ level of confidence

Table 6: The Result of Independent Samples Test for Rice Farm Productivity

\begin{tabular}{|c|c|c|c|c|c|c|}
\hline & & \multicolumn{2}{|c|}{ Levene's Test for Equality of Variances } & \multicolumn{3}{|c|}{ t-test for Equality of Means } \\
\hline & & $\mathbf{F}$ & Sig. & $\mathbf{t}$ & df & Sig. (2-tailed) \\
\hline \multirow{2}{*}{ Productivity } & Equal variances assumed & 0.04 & 0.84 & 0.33 & 58 & 0.74 \\
\hline & Equal variances not assumed & & & 0.33 & 57.99 & 0.74 \\
\hline
\end{tabular}


Table 7: The Result of Independent Samples Test of Rice Farm Revenue

\begin{tabular}{|c|c|c|c|c|c|c|}
\hline & & \multicolumn{2}{|c|}{ Levene's Test for Equality of Variances } & \multicolumn{3}{|c|}{ t-test for Equality of Means } \\
\hline & & $\mathbf{F}$ & Sig. & $\mathbf{t}$ & df & Sig. (2-tailed) \\
\hline \multirow{2}{*}{ Revenue } & Equal variances assumed & 3.41 & 0.07 & 2.03 & 58 & 0.04 \\
\hline & Equal variances not assumed & & & 2.03 & 42.77 & 0.04 \\
\hline
\end{tabular}

Table 9: The Result of Independent Samples Test of Rice Farm Cost

\begin{tabular}{|c|c|c|c|c|c|c|}
\hline & & \multicolumn{2}{|c|}{ Levene's Test for Equality of Variances } & \multicolumn{3}{|c|}{ t-test for Equality of Means } \\
\hline & & $\mathbf{F}$ & Sig. & t & df & Sig. (2-tailed) \\
\hline \multirow{2}{*}{ Cost } & Equal variances assumed & 0.03 & 0.85 & 0.42 & 58 & 0.67 \\
\hline & Equal variances not assumed & & & 0.42 & 57.06 & 0.67 \\
\hline
\end{tabular}

Table 11: The Result of Independent Samples Test for Sugarcane Farmers' Profitability

\begin{tabular}{|c|c|c|c|c|c|c|}
\hline & & \multicolumn{2}{|c|}{ Levene's Test for Equality of Variances } & \multicolumn{3}{|c|}{ t-test for Equality of Means } \\
\hline & & $\mathbf{F}$ & Sig. & $\mathbf{t}$ & df & Sig. (2-tailed) \\
\hline \multirow{2}{*}{ Profit } & Equal variances assumed & 2.72 & 0.10 & 2.03 & 58 & 0.04 \\
\hline & Equal variances not assumed & & & 2.03 & 42.89 & 0.04 \\
\hline
\end{tabular}

Table 12: The Result of Independent Samples Test of Feasibility for Sugarcane Farmers

\begin{tabular}{|c|c|c|c|c|c|c|}
\hline & & \multicolumn{2}{|c|}{ Levene's Test for Equality of Variances } & \multicolumn{3}{|c|}{ t-test for Equality of Means } \\
\hline & & $\mathbf{F}$ & Sig. & $\mathrm{t}$ & df & Sig. (2-tailed) \\
\hline \multirow{2}{*}{$\mathbf{R} / \mathbf{C}$} & Equal variances assumed & 0.67 & 0.06 & 1.59 & 58 & 0.12 \\
\hline & Equal variances not assumed & & & 1.59 & 35.40 & 0.12 \\
\hline
\end{tabular}

\subsection{The Cost Structure of Rice Farming in Banyumas Regency}

The costs in farming are classified into explicit costs or cash costs and implicit or calculated costs. The cash cost component in rice farming includes the cost of production facilities consisting of seeds, fertilizers, pesticides, and labors from outside of the family. Whereas, implicit costs include the cost of family labor, depreciation, own capital interest and own rent cost.

Table 8 illustrates that the total cost of rice farming spent by farmers implementing LIPM is lower than the total cost spent by those who do not implement LIPM, both in terms of the total cost of explicit and implicit costs. Costs that have considerable differences are the cost of pesticides, almost $200 \%$, because farmers who apply LIPM apply the IPM principles to reduce the use of chemical pesticides and replace them with organic pesticides. In addition, the planting of refugee plants on farmers' land can divert natural enemy insects so that the use of pesticides can also be reduced. However, by reducing chemical pesticides, farmers with LIPM use labor force more intensively, especially workers from outside the family, so that the cost of labor outside the family spent by farmers with LIPM is greater than the cost of labors spent by farmers without it.

Table 8: Rice Farming Cost Structure in Banyumas Regency (Rp/Ha)

\begin{tabular}{|c|c|c|}
\hline Description & LIPM Farm & $\begin{array}{c}\text { Non-LIPM } \\
\text { Farm }\end{array}$ \\
\hline Explicit cost & & \\
\hline Seed & $129,365.08$ & $155,456.35$ \\
\hline Fertilizer & $581,101.19$ & $690,366.07$ \\
\hline Pesticide & $6,226.19$ & $120,297.62$ \\
\hline Labor & $3,983,079.37$ & $3,810,029.76$ \\
\hline Total Explicit Cost & $4,699,771.83$ & 4.776 .149 .80 \\
\hline Implicit cost & & \\
\hline Family Labor & $9,3501.98$ & $118,303.57$ \\
\hline Depreciation & $64,634.92$ & $191,449.40$ \\
\hline Equity Interest & $250,165.93$ & $273,894.34$ \\
\hline Own Rent Cost & $3,480,955.75$ & $4,043,908.63$ \\
\hline Total Implicit Cost & $3,889,258.59$ & $4,627,555.95$ \\
\hline Total Cost & $8,589,030.42$ & $9,403,705.75$ \\
\hline
\end{tabular}

The mean difference test between the total cost of farming with LIPM and farmers without LIPM leads to the significance value of 0.85 in the F-test column; It is not assumed to be the same variance so that from the T-test column the value is 0.67 for the 2 -tailed test in which the value is greater than $10 \%$ margin of error which means that H0 is accepted. In other words, the total cost of LIPM farming and non-LIPM farming is not significant.

\subsection{Profitability and Feasibility of Rice Farming in Banyumas Regency}

Table 10: Profitability and Feasibility of Rice Farm in Banyumas Distric (per Ha)

\begin{tabular}{|c|c|c|}
\hline Description & LIPM Farm & Non-LIPM Farm \\
\hline Total Revenue & $58,162,910.12$ & $37,066,224.34$ \\
\hline Total Cost & $8,589,030.42$ & $9,403,705.75$ \\
\hline Total Profit & $49,573,879.70$ & $27,662,518.59$ \\
\hline R/C Ratio & 15.18 & 6.96 \\
\hline
\end{tabular}

Table 10 shows the profitability and feasibility of rice farming in Banyumas Regency in 2016. Farmers implementing LIPM programs have greater revenues, income, and profits than farmers who do not. LIPM farmers' revenue is almost twice as high as those who do not implement the program. This may be due to the participation of LIPM farmers in SLPHT. It is noteworthy that the age of the farmers who apply LIPM is relatively younger and more productive with higher level of education enable them to manage the farm more efficiently.

The feasibility of farming is as indicated by the value of $\mathrm{R} / \mathrm{C}$ ratio. Based on the feasibility analysis, the LIPM farmers and non-LIPM farmers are both feasible to cultivate ( $\mathrm{R} / \mathrm{C}$ ratio greater than 1). However, farmers who apply LIPM have higher $\mathrm{R} / \mathrm{C}$ ratio than those who do not.

The R / C ratio over cash cost per 1,000 plants for farmers applying LIPM is 15.28 . This means that any cash cost of Rp 100 will result in a revenue of Rp1,528. In contrast, farmers who do not apply R / $\mathrm{C}$ ratio over cash costs are 6.96 . This means that every cash expenditure of Rp 100 will generate revenue of Rp.696.

Table 11 highlights that the analysis of the mean difference test between profits by LIPM farmers and non-LIPM farmers results in the significance value of 0.10 in the F-test column; It is not assumed to be the same variance so that the value in the T-test column is 0.04 for the 2-tailed test where this value is less than the $5 \%$ margin of error which means that $\mathrm{H} 0$ is rejected. In other words, the revenue of the LIPM farmers and the non-LIPM farmers is significantly different at $95 \%$ level of confidence.

In contrast to the profit t-test, the analysis of the difference test between the feasibility of rice farming implementing LIPM and nonLIPM farming lead to the significance value of 0.06 in the F-test 
column; It is assumed to have the same variance as indicated by the T-test column of 0.12 for the 2-tailed test where this value is greater than the $10 \%$ margin of error, meaning that $\mathrm{H} 0$ is accepted. In other words, the feasibility of rice farming implementing LIPM and nonimplementing LIPM is not significant.

\section{Conclusion}

Pesticides cost and feasibility in the rice farm applying LIPM were less than those used in the rice farm not implementing LIPM in Banyumas Regency.

Productivity, revenue and profitability in the rice farm applying LIPM were higher than in those not implementing LIPM as seen in Pliken village in Banyumas Regency.

The independent T-test showed that LIPM and Non-LIPM Rice Farming in Pliken village were not significant in Banyumas Regency.

\section{Acknowledgement}

The researcher is grateful to the Institute of Education Fund Management (LPDP) and Faculty of Agriculture of Universitas Gadjah Mada for all the supports.

\section{References}

[1] Food and Agricultural Organization F. Innovative Rice Farming Systems and Conservation Agriculture 2017. Available from: http://www.fao.org/3/a-i5784b.pdf.

[2] Bottrel D. Integrated Pest Management. . Washington, D.C: US Government Printing Office; 1979.

[3] Untung K. Introduction of Integrated Pest Management. Yogyakarta: Gadjah Mada University Press; 1993.

[4] Concerning Cultivation of Plants, (1992).

[5] Plant Protection, (1995).

[6] Bajwa WI, Kogan M. Compendium of IPM definitions (CID). Electronic Publication (http://www ippc orst edu/IPMdefinitions). 1997.
[7] Hartiningsih. Analysis of Red Chili Farming with Integrated Pest Management Technology in Sawangan District, Malang Regency. Yogyakarta: Universitas Gadjah Mada; 2003.

[8] Untung K. Plant Protection Policy. Yogyakarta: Gadjah Mada University Press; 2007.

[9] Prabaningrum L, Tonny K., M., Witono A., \& Nikardi G. Four basic principles in application of integrated pest management 2015. Available from: http://balitsa.litbang.pertanian.go.id/ind/index.php/beritaterbaru/378-empat-prinsip-dasar-dalam-penerapan-pengendalianhama-terpadu-pht.html

[10] Ekowarso. National Program of Integrated Pest Management in Increasing Production of Food Crops in DIY. 1997.

[11] Bambang Sa. The Role of Integrated Pest Management in Supporting Regional Autonomy. 1997.

[12] Mahrub E. The Role of Universities in IPM Socialization. 1997.

[13] Untung K. Introduction of Integrated Pest Management. Yogyakarta: Gadjah Mada University Press; 2006.

[14] Sadikin S. Performance Post Paddy Pest Integrated Pest Management Technology Introductions. 1998.

[15] Saptatriningsih D. Impact of Integrated Pest Management Field School on Rice Poduction and Revenue in Moyudan Sub-District, Sleman Regency. Yogyakarta: Universitas Gadjah Mada; 2001.

[16] Untung K. Implementation of Integrated Pest Management Concept as a Process of Farmers Empowerment. 2002.

[17] Pujiharto. Effect of IPM Program on Production and Income of Cabbage Farmers in Banjarnegara District. Yogyakarta: Universitas Gadjah Mada; 2002.

[18] Maya DIT. Effect The Implementation of Integrated Pest Management on Cotton (Gossypium Hirsutum L.) Farms in Bayawab City, Negros Orientasl, Philippines. Philippines: University of the Philippines Los Banos; 2005.

[19] Hasibuan M. Study on Application of Integrated Pest Management (IPM) on Rice Farmers in South Tapanuli Regency. Medan: Universitas Sumatera Utara; 2008.

[20] Orr L, Stevens, M., and Mullen, J. . An Evaluation of the Economic, Environmental and Social Impacts of NSW DPI Investments in IPM Research in Invertebrate Rice Pests. . 2008.

[21] Amir HM, Shamsudin MN, Mohamed ZA, Hussein MA, Radam A. Economic evaluation of Rice IPM practices in MADA, Malaysia. Journal of Economics and Sustainable Development. 2012;3(9):4755.

[22] Popham WJ. Education Statistics-use and Interpretations (2nd Edition). New York: Harper \& Row; 1973. 